\title{
PERAN KIAI DALAM MEMBANGUN PARTISIPASI PEMILIH
}

\author{
Nurhadi, Sunarso \\ Program Pascasarjana Pendidikan Pancasila dan Kewarganegaraan \\ Universitas Negeri Yogyakarta, Jl. Colombo No. 1, Sleman Yogyakarta \\ Email:nhadiy10@gmaill.com
}

\begin{abstract}
This article aims to discuss the role of kiai in building voter participation. The method used is a qualitative approach. Data collection using observation, interviews, and observations. Analysis uses an interactive model. The results of the study show that scholars have 3 (three) roles in politics, namely as political political patrons, political elites, and political mediators. Kiai as political patrons become a reference in making political choices. Kiai are active political elites in the management of political parties and mass mobilization. Kiai as political mediators mediate in political conflicts.
\end{abstract}

Keywords: The role of kiai, voter participation, pesantren.

\begin{abstract}
Abstrak: artikel ini bertujuan untuk membahas peranan kiai dalam membangun partisipasi pemilih. Metode yang digunakan yaitu pendekatan kualitatif. Pengumpulan data dengan menggunakan cara observasi, wawancara, dan observasi. Analisis menggunakan model interaktif. Hasil kajian menunjukkan bahwa kiai memiliki 3 (tiga) peran dalam politik yaitu sebagai patron politik masyarakat, elit politik, dan mediator politik. Kiai sebagai patron politik menjadi acauan dalam menentukan pilihan politik. Kiai sebagai elit politik aktif dalam kepengurusan partai politik dan mobilisasi massa. Kiai sebagai mediator politik menjadi penengah dalam konflik politik.
\end{abstract}

Kata kunci: Peranan kiai, partipasi pemilih, pesantren.

Antusiasme masyarakat dalam upaya mensosialisasikan dukunganya dapat dikatakan sangat tinggi, hal ini dapat dilihat pada orientasi partisipan dalam mensosialisasikan calon yang di usung, seperti dalam proses kampanye antusiasme masyarakat sangat tinggi, serta kebanggaan dalam memakai atribut-atribut calon (stiker, gambargambar calon, pin, bendera-bendera partai dll) yang di usung. Tingkat partisipasi masyarakat dalam Pemilihan Umum (Pemilu) dapat dikatakan sebagai sebuah kemajuan budaya politik masyarakat. Almond \& Verba (1990:20-22) menyatakan bahwa kesadaran masyarakat akan pentingnya pertisipasi dirinya dalam menentukan calon menandakan adanya transisi bentuk budaya politik masyarakat dari politik parokial menjadi budaya politik subjek atau bahkan budaya politik partisipan.

Partisipasi politik di negara berkembang diperkenalkan dengan dua model. Dua model tersebut yaitu partisipasi yang bersifat demokratis dan partisipasi yang bersifat totaliter. Negara demokratis membuka kesempatan terhadap semua kalangan untuk mengambil bagian dalam proses pembuatan keputusan politik sebagai warga negara yang berpengaruh. Sedangkan yang totaliter memberikan tugas pokok sebagai partisipan. Walaupun pada kenyataannya bentuk demokrasi pastisipatif juga merupakan bagian dari pola partisipasi totaliter, baik dalam arti formal maupun fungsional, karena bentuk demokratis dari sistem partisipatif menuntut adanya keserasian kebudayaan politik dengannya(Almond \& Verba, 1990:3).

Seiring perkembangan zaman serta pengaruh arus modernisasi, arah demokratisasi menyasar struktur masyarakat yang selama ini dianggap tradisional yaitu pesantren. Pesantren dituntut menyesuaikan diri dengan lingkungan dan perkembangan zaman. Penyesuaian tersebut manyangkut sikap dan orientasi pesantren yang pada awalnya terbatas pada aspek kultur keagamaan dan sosial budaya, Seiring perkembangannya pesantren juga harus sigap dalam merespon hal-hal yang menyangkut sosialpolitik. Proses transisi pesantren ke arah politik 
pada awalnya memang menimbulkan pro kontra di kalangan masyarakat. Misalnya keterlibatan pesantren dalam politik menimbulkan dampak negatif bagi kiai yaitu hilangnya jati diri sebagai tokoh masyarakat akibat tindakan politik pragmatis serta timbulnya konflik horizontal di kalangan pendukung/jamaah kiai yang bersangkutan (Syamsuddin 2013:47-71). Tetapi disisi lain menekankan bahwa keterlibatan pesantren dalam dunia politik justru sebuah keharusan agar eksistensi pesantren dalam masyarakat lebih terasakan lagi (Falah, 1999:165).

Pro kontra orientasi pesantren kearah politik ini yang kemudian harus disikapi oleh kiai sebagai pengasuh yang bertanggung jawab atas majunya perkembangan pesantren. Karena bagaimanapun partipasi pemilih di indonesia dapat dilihat dalam dua bentuk yaitu melalui partai politik (parpol) dan non partai politik, partisipasi non parpol juga sangat besar pengaruhnya seperti diantaranya jaringan sosial, sosial keagamaan, jaringan keagamaan yang melibatkan gender, jaringan kekerabatan, jaringan etnik, pembelahan sosial, ketokohan, ulama/ kiai, atau mobilisasi politik hegemoni yang dipraktikan orde baru. Jaringan yang terbentuk merupakan aspek penting dalam melihat bahwa ketokohan, jaringan keagamaan, ulama/kiai merupakan bagian penting dalam membangun partisipasi pemilih pada pemillihan umum (Nugroho, 2011:202-214).

Setiap individu memiliki tugas masing-masing untuk dikerjakan sesuai kemampuan yang dimiliki, tugas-tugas ini kemudian menghadirkan perilaku untuk saling mempengaruhi. Peran merupakan konsep tentang apa yang harus dilakukan oleh individu dalam masyarakat dan meliputi tuntutantuntutan prilaku dari masyarakat terhadap seseorang dan merupakan perilaku individu yang penting bagi struktur sosial masyarakatWulansari (2009:106). Kemudian, orientasi individu atau kelompok diluar sikap normatifnya (kebiasaan) akan membentuk suatu sikap yang berbeda atau yang sering disebut sebagai peranan. Peranan lebih kepada atribut dari status, dan perilaku yang diarapkan oleh anggota-anggota lain dari pemegang status itu sendiri Duverger, (2010: 102).

Kemampuan melakukan lebih terhadap sekolompok individu melekat pada setiap orang yang mampu mempengaruhi individu atau kelompok dari kalangangnya dalam hal ini tokoh agama. Tokoh agama merupakan sejumlah orang Islam yang karena pengaruhnya begitu luas dan besar dalam masyarakat muslim baik pengetahuannya perjuangan menegakkan sariat Islam perilaku yang baik dan diteladani maupun karismatiknya cukup disegani masyarakat (Malik, 1994:36). tokoh agama termasuk sebagai orang yang mempunyai peranan dalam lingkungan masyarakatnya.

Peranan tokoh agama sangat penting dalam mengandalikan ketegangan sosial yang terjadi di masyarakat pada zaman yang semakin modern dan demokratis. Kepemimpinannya dapat dikatakan sebagai informal leadership kepemimpinan Karena pengakuan masayarakat akan kemampuan seseorang untuk mejalankan kepemimpinan (Soekanto, 2003:318). Tokoh agama merupakan tokoh politik dilihat dari struktur politik sebagai kelompok sosialisasi politik, yang juga termasuk di dalamnya keluarga, pendidikan, kelompok sebaya, dan kelompok kerja (Rush \& Althof, 2007:35-37).

Beberapa kelompok dalam struktur sosialisasi politik bisa berperan dalam membangun partisiapasi politik. Partisipasi politik ialah keterlibatan individuindividu dalam bermacam-macam tindakan dalam kehidupan politik, baik berupa kegiatan memberi atau tidak memberi dukungan dukungan politik dalam berbagai kegiatan terutama dalam kegiatan kampanye dan pemberian suara dalam pemilihan umum serta kegiatan dalam proses penetapan kebijakan publik (Arifin, 2014:64). Tokoh agama bisa bertindak untuk memberi atau tidak memberi dukungan politik pada kegiatan kampanye dan pemberian suara dalam pemilu. Tokoh agama merupakan pemimpin suatu agama yaitu; kiai/ulama, pendeta dan pastor.

Pemilihan umum secara langsung membawa Indonesia kearah demokratisasi. Masyarakat yang telah memiliki hak suara dalam pemilu dapat menentukan kebijakan, menurut Josep Schumpeter (1883-1950), pemilihan umum pada dasarnya untuk mendapatkan suatu pemerintahan atau suatu badan penengah lainnya yang pada saatnya menghasilkan badan eksekutif nasional atau pemerintah. Pemilihan umum sebagai suatu proses untuk mendapatkan eksekutif dan pemerintah sehingga menurutnya peranan pemilih tidak untuk memutuskan masalahmasalah politik tetapi memilih orang-orang yang akan membuat keputusan-keputusan (Varma, 2010:211). Penjaringan ini melahirkan kelompokkelompok tertentu yang mampu mempengaruhi kelompok lain, baik secara individu ataupun kelompok yang sering disebut sebagai elit. Lebih 
lanjut dijelasan setidaknya ada dua katagori yang luas untuk mengartikan elit. Pertama, sekolompok kecil manusia yang berkemampuan untuk memimpin/memerintah dan menduduki posisi penting. Kedua, sekolompok besar massa yang ditakdirkan untuk diperintah. Mengacu pada teori tersebut, individu ataupun kelompok yang mampu memerintah sekolompok massadapat dikatakan sebagai elit karena melihat pengaruhnya dalam masyarakat sebagai orang yang mampu memerintah sekelompok orang (Varma, 2010:197).

Transisi pesantren kearah sosial politik banyak berkembang di pulau Madura, pada tenggang waktu antara tahun 2010-2016 hampir dipastikan kepala daerah yang menjabat di empat kabupaten di Madura merupakan kiai atau afiliasi dukunganya sebagian besar pondok pesantren (ponpes).Pada pemilukada 2010 di kabupaten sumenep yang dimenangkan Kiai Busyro Karim sekaligus menggantikan Kiai Ramdlan Siradj. Sedangkan pada Pilkada Kabupaten Pamekasan, Sampang dan Kabupaten Bangkalan pada periode tahun 2012, merupakan pencaturan kiai dalam pilkada diantaranya, Kiai Kholilurrahman dan Kiai Achmad Syafii pilkada Pamekasan, Kiai Fannan Hasib dan Fadhilah Budiono Kabupaten Sampang dan Kiai Makmun Ibnu Fuad merupakan putra Kiai Fuad Amin Imron periode sebelumnya di Kabupaten Bangkalan (Prastiwi, 2015:202-220). Pesantrentidak bisa lepas dari pergulatan politik, salah satu diantaranya kabupaten Pamekasan. Sejak hadirnya pemilihan umum secara langsung salah satu pesantren di Pamekasan sangat inten dengan pesta demokrasi utamanya dalam pemilukada. Ponpes Darul Ulum Banyuanyar dapat dipastikan disetiap pemilukada selalu aktif menghadirkan kadernya untuk maju pada pemilukada baik sebagai calon bupati ataupun calon wakil bupati untuk bersaing dalam pilkada. Tampilnya kader dari pesantren tersebut tidak lepas dari peranan penting kiai ponpes Darul Ulum Banyuanyar yang juga aktif sebagai dewan syariah Partai Persatuan Perbangunan (PPP). Tujuan dari penulisan artikel ini adalah mengungkapkan peranan kiai dalam membangun partisipasi pemilih di pesantren Darul Ulum Banyuanyar pada pelakasanaan pemilukada.

\section{METODE}

Kajian menggunakan metode deskriptif kualitatif untuk mendeskripsikanperanan kiai dalam membangun partisipasi pemiilih di pesantren Darul Ulum Banyuanyar pada pemilukada kabupaten pamekasan 2018. Sebagaimana diungkapkan Moleong (2007:6) penelitian kualitatifberusaha memahami fenomena tentang apa yang dialami oleh subjek penelitian Misalnya menyangkut perilaku, persepsi, motivasi, tindakan secara holistik. Studi kasus pada umumnya merupakan suatu penelitian intensif mengenai seseorang (bisa merujuk langsung pada orang, tempat, maupun peristiwa). Studi kasus berusaha untuk menyelidiki satuan sosial terkecil seperti keluarga, suatu perkumpulan, suatu sekolah, atau suatu kelomok remaja secara mendalam (Dantes, 2012:51).

Pengumpulan data dilakukan dengan menggunakan wawancara, observasi, dan dokumen. data yang diperoleh melalui wawancara merupakan data primer sedangkan data yang diperoleh dari observasi dan dokumen meupakan data sekunder.Penentuan subjekmenggunakan teknikpurposive dengankiai pondok pesantren Darul Ulum Banyuanyar dengan informan kunci.

\section{HASIL DAN PEMBAHASAN}

\section{Perana Kiai dalam Membangun Partisipasi Pemilih di Pesantren}

Perkembangan politik yang semakin demokratis membuka ruang bagi segenap lapisan masyarakat untuk dapat berperan dalam perpolitikan begitu juga bagi para elit lokal dalam hal ini kiai-kiai sebagai salah satu elit lokal memiliki peran yang sangat kuat. Dalam masyarakat Madura kiai dan politik tidak dapat dipisahkan. Berdasarkan hasil kajian ditemukan beberapa peran kiai dalam pemilukada, yaitu sebagai patron politik masyarakat, elit politik, dan mediator politik.

\section{Kiai Sebagai Patron Politik Masyarakat}

Interaksi masyarakat Madura terbentuk dalam tatanan masyaraktnya sebagai keteladanan setruktural yang harus ipatuhi dan dijunjung tinggi, tatanan tersebut merupakan norma yang ada sebagai karakter dalam kehidupan sehari-hari masyarakatnya,tatanan keteladalan ini terbentuk dalam ungkapan falsafah Madura bhuppa', bhappu', ghuru, rato (Orang tua, Guru, Pemerintah) merupakan nilai-nilai positif yang melandasi hubungan antar manusia (Sukri, 
1999:143-153). Tingkatan tersebut merupakan kedudukan untuk memposisikan orang-orang yang dihormati pada tingkatan pertama yang harus dijunjung tinggi.

Hirarki tersebut dalam tatanan sosial masyarakat tidak hanya sebagai kepercayaan yang berlaku dalam sistem sosial budaya dan sosial keagamaan tetapi juga menjadi legitimasi dalam kontek afiliasi politik masyarakat pada umumnya, kedudukan ini akan sangat berpengaruh dalam menentukan arah politik. Kiai sebagai bagian tatanan masyarakat yang disegani juga berlaku dalam semua interaksi sosial dalam hal ini juga berlaku dalam menentukan pilihan poliitk masyarakat/santri, (ghuru) guru sebagai orang yang memberikan pengetahuan dalam masyarakat baik ilmu agama dan umum akan diakui sebagai bagian dalam tatanan ini, guru dalam kontek masyarakat Pamekasan meliputi guru/pengajar (pengajar sekolah umum), ustaz/ustazah (pengajar madrasah, langgar/surau) juga (keyaeh) kiai sebagai kiai pondok, kiai langgar/surau, kiai dukun, dalam kontek kiai dukun hanya akan digunakan oleh orang-orang yang berobat atau meminta bantuannya dan umumnya orang-orang diluar masyarakat sekitarnya.

Sehingga dalam pemilukada (ghuru) guru ataupun kiai menjadi acuan bagi masyarakat/santri dalam menentukan pilihan, dan banyak ditemui dalam menghadapi pemilihan umum masyarakat/ santri akan datang bertanya dan ingin mengetahui kemana arah dukungan kiai dalam suatu pemilihan, tujuan tersebut untuk mengetahui dukungan dan kemudian mengikutinya sebagai bentuk kepatuhan terhadap petuntjuk kiai. Setidaknya ada dua faktor yang menjadikan kiai kuat dan disegani masyarakat pertama, kiai adalah orang berpengatahuan luas yang kepadanya penduduk/masyarakat belajar pengetahuan, kedua, kiai biasanya berasal dari keluarga berada (Turmudi, 2004:95).

Sebagai patron politik kiai menjadi salah satu elit politik yang ditunggu sikap politiknya pada pemilukada, sehingga perlu untuk menyikapi perkembangan politik yang sedang berlangsung. Biasanya cara yang dilakukannya menggunakan mimbar atau panggung politik, seiring berkembangnnya teknologi pola yang dilakukan berbeda.Perkembangan teknologi menjadi alternatif untuk memyampaikan sikap kiai dalam mendukung paslon dan mempengaruhi patisipasi pemilih, penggunaan media sosial sebagai sarana sosialisasi. Berita politik memiliki efek yang lebih besar daripada sumber persuasi seperti situs web kandidat dan iklan, sebagai sumber signifikan untuk membangun partisipasi politik (Thorson \& Eunjin, 2017:231-244). Penggunaan media sosial dalam politik juga termasuk seperti menggunakan Twitter dan situs media sosial lainnya memiliki potensi untuk menarik orang yang tidak terlibat ke dalam politik (Bekafigo \& McBride, 2013:625-643).

Meskipun berbeda tujuan penggunaannya melihat pentingnya media sosial Salahuddin Wahid memanfaatkan media sosial untuk mempromosikan religiusitas inklusif dan penghormatan hak minoritas melalui media sosial; karena itu dia aktif mempromosikan idenya melalui media sosial terutama Twitter(Widiyanto, 2014:271-307).Ilustrasi teresbut menggambarkan pentingnya media sosial dalam unutk menyampaikan informasi publik. Sarana media sosial ini cukup inten digunakan untuk mempromosikan paslon dalam kontek pemilukada di kabupaten pamekasan, sosialisasi calon serta agenda kampanye sering di dampaikan melalui media sosial seperti (facebook dan whatsaap). Pesan-pesan politik banyak sekali menghiasi media sosial. Fenomenatersebut sebagai pengaruh perkembangan tehnologi tidak dapat dipisahkan dari kebutuhan penting dalam sosialisasi politik.

Kemudian, untuk mengilustrasikan hubungan positif antara penggunaan media sosial facebook, youtobe, whatsaapdengan partisipasi politik bisa diperhatikan bagaimana media sosial menjadi sarana informasi penting dari aktor politik. Penggunaan media sosial memiliki hubungan langsung dengan aktor politik yang menunjukkan bahwa partisipasi langsung dari masyarakat secara bersama (Tang \& Lee, 2013:763-773). Seperti halnyayoutube mempengaruhi sikap terhadap politik. saluran youtube membuat sinisme terhadap pemerintah AS namun juga memiliki kesadaran yang tinggi bahwa mereka mempengaruhi sistem politik (Terri \& David, 2011:626-644). hal yang sama pada saat ini, whatsapp telah dimanfaatkan oleh tokoh masyarakat untuk berkomunikasi menyampaikan pesan kepada sasarannya (Trisnani, 2017:112). Mengindikasikan bahwa media sosial merupakan kebutuhan yang tidak hanya bersifat pribadi untuk berkomunikasi dengan orang lain tertapi juga menjadi alternatif untuk menyampaikan informasi secara cepat kepada masyarakat terkait isu-isu politik yang berkembang serta orientasi politik elit lokal dalam hal ini kiai. 
Kiai sebagai patron masyarakat sangat menentukan arah dukungan pada pemilihan umum dan kedudukanya sebagai elit lokal dan juga memimpin pesantren. Kiai juga merupakan tokoh agama dan sebagai agen sosialisasi politik, sehingga secara otomatis tidak bisa lepas dari kepentingan politik seperti diketahui bahwa sosilaisasi politik merupakan suatu proses sosialisasi sejak masa kanak-kanak sampai usia dewasa yang di dalamnya melibatkan keluarga, sekolah dan juga tokoh agama (Rush \& Althof, 2007:35).Upaya yang dilakukan semakin berkembang dengan menjadikanmedia sosial sebagaisaranauntuk menyampaikan aspirasi bagi kalangan elit lokal dan juga sarana untuk mensosialisikan dukungannya sehingga bisa diketahui masyarakat umum dan tentunya untuk meraih dukungan pada pemilihan yang sedang berlangsung.

\section{Kiai Sebagai Elit Politik}

Kiai sebagai acuan masyarakat dalam menentukan orentasi politiknya pada pemilihan umum dan dianggap sebagai orang yang mampu mempengaruhi dan menentukan kehidupan serta perubahan dalam masyarakat walaupun tidak sepenuhnya masyarakat tergantung kepadanya, inilah yang kemudian disebut sebagai golongan elit (Kartodirdjo, 1992:131). Kaum elit menurut Putnam digambarkan menjadi; pertama, secara eksternal bersifat homogeny, bersatu dan memiliki kesadaran kelompok, kadang memiliki nilia-nilai kesetiaan dan kepentingan bersama dalamsuatu pandangan yang berbeda. Kedua, kaum yang mengatur dirinya hidupnya sendiri (self perpetuating) keanggotannya berasal dari suatu lapisan masyarakat yang terbatas, dan memilih pemimpin dari kalangan istimewa yang terdiri dari beberapa orang. Ketiga, elit yeng sifatnya otonom, kebal gugatan dan hanya mementingkan kelompoknya (Chalik, 2017:36-37).

Kiai sebgai elit lokal yang mempunyai pengaruh kuat dalam masyarakat untuk membangun partisipasi politik dimasyarakat karena sebenarnya hal ini tidak bertentangan dengan agama, agama (islam) dalam pandangan pradigma mengakui islam sebagai sistem kemasyarakatan termasuk juga sebagai sistem politik. Kedua entitas tersebut mengisyaratkan pradigma fikih berkembang sesuai perkembangan ilmu modern oleh karenanya memungkinkan umat Islam untuk berpartisipasi aktif dalam sistem politik modern (Rohmat, 2014:309-329).Sebagai elit lokal (local strongmen) menjadi jembatan bagi kiai untuk dengan mudah masuk dalam lingkungan politik praktis. Seringkali ditemui dibanyak tempatkiai aktif dalam parpol dan bahkan maju sebagai calon dalam pemilihan. Hal ini yang terjadi pada pemilukada kabupaten pamekasan, kiai terlibat secara langsung dalam kepengurusan partai politik (parpol) walaupun tidak menjadi maju menjadi paslon dalam pemilihan.

Pada saat bersamaan kiai bisa memobilisasi massa melalui pergerakan organisasi masyarakat (Ormas) dan lembaga swadaya masyarakat (LSM) berfungsi memperjuangkan, menjembatani, dan membela kepentingan rakyat dari kepentingan pemodal dan politik praktis. Tujuan utama bagian ini harus megarah kepada orientasi positif, bahwa kekuatan dan kemampuan kolektivitas pengorganisasian massa, Ormas dan LSM terlibat mengawasi kebijakan-kebijakan atau programprogram pembangunan demi kepentingan publik (Herdiansah, 2016:49-67). lebih lanjut organisasi massamenunjukkan bahwa organisasi berbasis komunitas efektif dalam promosi sosial, spiritual, dan saling membantu dalam mengatur dan mengoordinasikan pekerjaan. Kasus organisasi semacam itu tidak selalu mengecilkan peran yang dimainkan oleh organisasi masyarakat di bidang pembangunan (Mequanent, 2013:494-520).

Mobilisasi massa dapat dinilia sangat efektif untuk setidaknya mengurangi menekan pengeluaran kampanye implikasinya terhadap efektivitas biaya mobilisasi sebagai strategi dalam politik, dan bukti efeknya pada partisipasi massa dalam pemilihan, polarisasi elit politik dan pemilih, dan perubahan regulasi kampanye dan pemilihan, saya berpendapat, telah mempengaruhi peluang, insentif, dan sumber daya untuk mobilisasi sebagai strategi pilihan untuk kampanye Amerika (Hansen, 2016:149-157).Kebutuhan akan dukungan massa yang luas menjadi tujuan utama dalam setiap proses pemilihan. Penggunaan sarana dalam bentuk asosiasi sangatlah penting juga dalam upaya membangun partisipasi pemilih, Penciptaan komunitas politik nasional adalah proses yang berlarut-larut dalam jangka panjang membentuk perubahan-perubahan yang signifikan kemudian memunculkan bentuk politik yang sangat demokratis dan partisipatif(Martin, 2014:173-195).

Gerakan ini juga bisa dikatakan sebagai gerakan social movements. Tarrow (1994) social movements merupakan tantangan kolektif oleh or- 
ang-orang yang mempunyai tujuan yang sama berbasis solidaritas (Budiarjo, 2008:382-383). Soliditas gerakan pada pemilukada kabupaten Pamekasan tergambar pada gerakan laskar itiqomah (Laris) bergerak dalam bentuk perilaku kolektif yang berakar oleh kepercayaan dan nilainilai tentang sam'an wa ta'dziman (saya melihat saya mengikuti) atau sami'na wa ato, na (saya meilihat dan mengikuti) yang menjadi kebutuhan kiai mereka ikuti dan dilaksanakan. Sehingga, kehadiran organisasi yang mengakomodir kebutuhan kiai menjadi sumbu utama dalam upaya menggalang dukungan santri/alumni dan masyarakat.

\section{Kiai sebagai Mediator Politik}

Mediator secara harfiyah berasal dari kata mediasi yaitu sebagai upaya menyelesaikan konflik dengan melibatkan pihak ketiga yang netral. Mediator adalah pihak yang bersifat netral dan tidak memihak, yang berfungsi membantu para pihak dalam mencari berbagai kemungkinan penyelesaian sengketa (Soemartono, 2006:119120).Mediator dalam kontekpolitk seringkali bekerja sebagai orang yang diuntungkan, mediator hadir dalam suatu perbedaan pandangan antara beberapa belah pihak dan mencapai kesepakatan antara keduanya kemudian diuntungkan oleh bersatunya kekuatan yang kemudian menjadi kekuatan massa yang solid.

Kiai sebagai mediator dalam upaaya menyatukan perbedaan pandangan dalam kaitannya dengan pilihan politik memang sulit untuk dapat benar-benar bisa melepaskan diri dari identitas dirinya sebagai tokoh agama.Penggunaan fatwa ataupun istilah tertentu sering digunakan dalam mempangaruhi pemilih, fatwa atau istilah yang berkembang adalah sesuatu yang wajar sebagai cara untuk menarik hati pemilih selama hal itu tidak mengandung citra negatif. Karena pada dasarnya identitas politik ulama mungkin tampak sulit terpisah dari minat dan agenda politik mereka, misalnya apakah ulama berafiliasi dengan partai Islam atau mengambil peran dalam politik, sehingga ulama dapat mengeluarkan fatwa-fatwa tertentu tentang orientasi politiknya (Winarni, 2014:257-269).

\section{DAFTAR RUJUKAN}

Almond, G., \& Verba, S. 1990. Budaya politik. Jakarta. Bumi Aksara.
Pada saat-saat tertentu sesuai momentum yang ada kadang istilah-isitilah agamis bisa membangkitkan gairah masyarakat untuk mendukung paslon pada pemilihan umum, dan hal ini cukup efektif untuk menarik simpati masyarakat.Sebagian besar berpartisipasi dalam politik pribadi. Misalnya, memilih, berdoa bagi kandidat, kampanye, memakai propaganda politik, dan berpartisipasi dalam organisasi politik, mereka juga menggunakan posisi mereka untuk mempengaruhi pengikut mereka menggunakan mimbar sebagai kendaraan untuk terlibat dalam "pidato" politik yang memobilisasi jemaah mereka (Kadoe \& Husein, 2015:131-158).Perpedaan pendapat dalam penentuan paslon seperti menggunakan istilah "islah" atau mengabdi kepada guru (kyaeh) dan juga bersama ulama menjadi isu-isu yang cukup kuat untuk menyatukan kelompok yang berbeda pandangan dilihat sebagai langkah dakwah dalam memilih salah satu paslon sehingga momentum yang tepat sangat mungkin untuk menjadi istilah atau fatwa sebagai sarana membangun partisipasi pemilih.

\section{SIMPULAN}

Peranan kiai dalam membangun partisipasi yaitu; Pertama, sebagai patron politik masyarakat. Kiai di masyarakat menjadi teladan dan sangat disegani, termasuk dalam hal politik. Kiai menjadi salah satu pertimbangan santri dan masyarakat dalam pemilihan. Teknologi informasi menjadi sarana untuk menyampaikan sikap politiknya para kiai, pesan disampaikan melalui video whatsaap, facebook dan youtobe.Kedua, kiai sebagai Elit Politik dan tokoh agama mempunyai peranan yang penting dalam membangun partisipasi pemilih. Keberadan kiai politik dapat ditemuai sebagai perngurus partai dan sebagai pendukung paslon tertentu serta memobilisasi massa melalu organisasi Laris (laskar istiqomah). Ketiga, kiai sebagai mediator politik menjadi mediator kelompok yang berbeda pendapat.Kedudukan kiai sebagai tokoh agama membangun partisipasi pemilih sering menggunakan panggung dakwahsebagai arenauntuk menyampaikan pesan politis.

Bekafigo, M. A. \& McBride, A. 2013. Who tweets about politics?: Political participation of twitter users during the 2011 guber- 
natorial elections. Social Science Computer Review. 31(5), 625-643. https:// doi.org/10.1177/0894439313490405

Budiarjo, M. 2008. Dasar-dasar ilmu politik. Jakarta: PT Gramedia Pustaka Utama.

Chalik, A. 2017. Pertarungan elit dalam politik lokal, Yogyakarta: Pustaka Pelajar.

Dantes, N. 2012. Metode penelitian. Yogyakarta: Andi.

Duverger, M. 2010. Sosiologi politik. Jakarta: Rajagrafindo Persada.

Falah, dkk. 1999. (ed). Pesantren masa depan. Wacana pemberdayaan dan transformasi pesantren. Bandung: Pustaka Hidayah.

Hansen, J. M. 2016. Mobilization, participation, and political change. Party Politics, 22(2), 149-157. https://doi.org/10.1177/ 1354068815605677

Herdiansah, A. G. 2016. Peran organisasi masyarakat (Ormas) dan lembaga swadaya masyarakat (LSM) dalam menopang pembangunan di Indonesia. Sosioglobal Jurnal Pemikiran dan Penelitian Sosiologi, 1(1), 49-67

Kadoe, N. L \& Husein, F. 2015. Ulama, state, and politics in myanmar. Al-Jâmi 'ah, Vol. 53, no. 1 , pp. 131-158, doi: 10.14421/ ajis.2015.531.131-158

Kartodirdjo, K. 1992. (ed.), Pesta demokrasi di pedesaan. Yogyakarta: Aditya Media.

Martin, J. A. 2014. Mobile media and political participation: Defining and developing an emerging field. Mobile Media \& Communication, 2(2), 173-195. https://doi.org/ $10.1177 / 2050157914520847$

Mequanent, G. 2013. Community development and the role of community organizations: A study in Northern Ethiopia. Canadian Journal of African Studies/Revue canadienne des études africaines, 32 (3), 494-520.

Moleong, L. J. 2007. Metodologi penelitian kualitatif. Bandung: PT. Remaja Rosdakarya.

Nugroho, K. 2011. Ikhtiar teoritik mengkaji peran partai dalam mobilisasi politik elektoral. Departemen Politik.Universitas Airlangga, 24(3), 202-214.
Rohmat, S. (2014):The fiqh paradigm for the pancasila state: Abdurrahman Wahid's Thoughts on Islam and. Al-Jâmi'ah: Jurnal Studi Islam, Vol. 52, 2, hlm. 309329, doi: 10.14421 / ajis.2014.522.309-329.

Rush, M. \& Althof, P. 2007. Pengantarsosiologi politik. Jakarta: PT Rajagrafindo Persada.

Sukri, R. A. 1999. Konsep "bapa' babu' guru rato" pada masyarakat madura sebagai wujud pengamalan sila ke-2 pancasila. Jurnal filsafat, seri ke-30 oktober: 143-153.

Syamsuddin, M. 2013. Kiai dan politik: keterlibatan kiai madura dalam politik praktis. Sosiologi Reûektif, 7(2), 47-71.

Tang, G. \& Lee, F. L. F. 2013. Facebook use and political participation. Social Science Computer Review, 31 (6), 763-773.

Terri, L. T. \& David, A. D. 2011. An experiment of campaign effects during the youtube election. New Media \& Society, 13 (4), 626-644.

Thorson, E. Swafford, S \& Eunjin, K. 2017. Newspaper news exposure predicts political participation. Newspaper Research Journal, Vol. 38(2) 231-244. DOI: 10.1177/ 0739532917716445

Trisnani. 2017. Pemanfaatan whatsapp sebagai media komunikasi dan kepuasan dalam penyampaian pesan dikalangan tokoh masyarakat. Komunika, 6 (3), 1-12.

Turmudi, E. 2004. Perselengkuhan kiai dan kekuasaan. Yogyakarta: LKiS Yogyakarta.

Varma, S. P. 2010. Teori politik modern, ed, tohir efendi dkk. Jakarta: Rajagrafindo Persada.

Widiyanto, A. 2014. Salahuddin wahid and the defence of minority rights in contemporary of minority rights in contemporary. AlJâmi'ah: Jurnal Studi Islam. 52(2), 271307, doi: 10.14421 / ajis.2014.522.271-307

Winarni, L. 2014. The political identity of ulama in the 2014 Indonesian presidential pemilihan. Al-Jâmi 'ah: Journal of Islamic Studies, Vol. 52, no. 2, pp. 257-269. doi: 10.14421/ ajis.2014.522.257-269

Wulansari, D. 2009. Sosiologi konsep dan teori. Bandung; Refika Aditama. 